\title{
ON SCREENING OF ANTIVIRAL SUBSTANCES PRODUCED BY STREPTOMYCES AND ON AN ANTIVIRAL SUBSTANCE ACHROMOVIROMYCIN
}

\author{
Hamao UMEZAWA, Tomio TAKEUCHI, Yoshiro OKAMI, \\ AND TADAKATSU TAZAKI
}

The National Institute of Health, Tokyo, Japan

(Received: November 1st, 1952)

The number of antiviral antibiotics is rather few in comparison with that of antibacterial antibiotics. Those worthy to be cited, among the former, are ehrlichin (1), viscosin (2) and abikoviromycin (3). The slow progress of the study of antiviral antibiotics may be due to the complexities of their testing procedures, but it may not be due to their rarity. Under the present circumstance, it may be worthy to report the writers' results of screening antiviral substances. In this paper, the methods of searching antiviral substances produced by streptomyces, as well as the description of a new antiviral antibiotic, achromoviromycin, are presented.

Screening of antiviral substance produced by streptomyces

There are several kinds of procedures in searching antibacterial antibiotics. They can be classified into two main groups, one is the testing of inhibition phenomena around the growth of an antibiotic producer on agar medium and the other is the testing of the existence of antibiotic in liquid culture. In searching antiviral substances, too, those two kinds of procedures can be used. After completion of the growth of a producer on agar plate, the medium around the colony contains an antiviral substance. If that part is added to a virus suspension, the antibiotic diffuses into the suspension and inactivates the virus or inhibits its multiplication in the sensitive animal. In this method, the medium containing antibiotic should be taken out in a sterile state. Sometimes, however, particularly in the case of a microorganism which forms a lot of spores or which migrates quickly in the medium difficulties may occur in obtaining a sterile sample. An antiviral substance which can attack the virus multiplying in living cells seems to be limited to a group of substances with small molecular weight in order to diffuse quickly through semi-permeable cell membrane. The use of such membrane makes it possible to get a sterile sample. A method which the writers tentatively named "agar diffusion method" is based on the above considerations. As shown in Fig. 1, a sterile cellophane bag was put in glycerol nutrient agar and a strain of streptomyces to be tested was streaked around the bag. After 4 or 5 days' incubation at $27-28^{\circ} \mathrm{C}$ to secure full growth, a broth emulsion at $10^{-5}$ dilution of the brain of a mouse infected with Japanese $B$ encephalitis virus was put in the cellophane bag and kept for 24 hours at $0^{\circ} \mathrm{C}$. Then, the emulsion was taken out and 


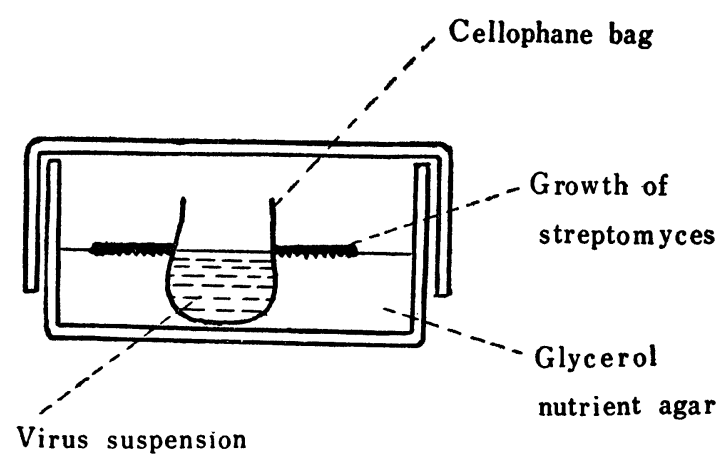

Fig. 1. Agar diffusion method for screening antiviral substances

injected into the brains of 5 mice. If 4-5 mice survived, the result was decided to be positive, and if 2-3 mice survived, it was decided to be doubtful. The experimental findings of 135 strains examined are shown in Table 1.

Table 1. Examination of strains on the production of antiviral substances to Japanese B encephalitis virus by agar diffusion method

\begin{tabular}{|c|c|c|c|}
\hline $\begin{array}{c}\text { Number of } \\
\text { strains tested }\end{array}$ & Species & $\begin{array}{c}\text { Antiviral } \\
\text { effect }\end{array}$ & Antibiotic \\
\hline 2 & S. griseus & - & Streptomycin \\
\hline 2 & S. griseus (pink variant) & - & \\
\hline 1 & & - & To Gram positive bacteria \\
\hline 1 & S. griseus & - & Grisein-like \\
\hline 1 & & + & \\
\hline $\mathbf{5}$ & S. lavendulae & - & Streptothricin A \\
\hline 1 & S. microflavus & - & ” \\
\hline 1 & S. albidoflavus & + & " \\
\hline 1 & S. albus & - & \\
\hline 2 & S. fradiae & $?$ & Streptothricin B (neomycin) \\
\hline 1 & & - & \\
\hline 1 & S. venezuelae & - & Chloramphenicol \\
\hline 19 & S. thioluteus & - & Thiolutin \\
\hline 2 & & $?$ & \\
\hline 1 & S. flaveolus & - & Actinomycin \\
\hline 1 & S. flavu's & - & \\
\hline 1 & S. griseoluteus & - & Griseolutein \\
\hline 1 & S. nitrosporeus & - & Nitrosporin \\
\hline 1 & S. exfoliatus & - & Exfoliatin \\
\hline 9 & S. abikoensis & - & Abikoviromycin \\
\hline 3 & $(\mathrm{Z}-1-4)$ & + & \\
\hline 1 & S. rubescens & - & Abikoviromycin \\
\hline 2 & Micromonospora fuscus & - & To bacteria and fungi \\
\hline 4 & $?$ & - & To Gram positive bacteria \\
\hline 6 & $?$ & - & To bacteria and fungi \\
\hline 61 & ? & - & Slightly or none \\
\hline 2 & $(\mathrm{Z}-4-1)$ & + & Slightly \\
\hline 2 & $? \quad(\mathrm{Z}-3-3)(\mathrm{Z}-8-1)$ & $?$ & Slightly \\
\hline 135 & $\begin{array}{l}(+): 5 \\
(?): 6\end{array}$ & & \\
\hline
\end{tabular}


Another screening method which the writers tentatively named "ordinary method" is the testing of the activity of a broth filtrate of streptomyces. A strain to be tested was shaken-cultured $(150 \mathrm{ml}$ medium per flask of $500 \mathrm{ml}$ volume, reciprocating schaking machine, 120 strokes per minute, $8 \mathrm{~cm}$ amplitude) in glycerol (1.0\%) nutrient broth and glucose (1.0\%) nutrient broth. Two kinds of the cultured broths were mixed and filtered through Seitz filter. The filtrate was added to the same volume of the infected mouse brain emulsion in a dilution of $10^{-4}$. Test viruses used were Japanese $B$ encephalitis virus and western equine encephalitis virus. The mixture was injected intracerebrally into mice. In another experiment, an infected mice brain emulsion at $10^{-4}$ dilution was injected intracerebrally and $0.3 \mathrm{ml}$ of the mixed broth filtrate was injected subcutaneously. Test viruses used were the same as above. The results are shown in Table 2.

Table 2. Examination of strains on the production of antiviral substances to Japanese $B$ encephalitis and western equine encephalitis viruses tested by ordinary methods

\begin{tabular}{|c|c|c|c|}
\hline Strains & $\begin{array}{l}\text { Inhibitory } \\
\text { effect to } \\
\text { Japanese } \\
\text { encephalitis }\end{array}$ & $\begin{array}{l}\text { Inhibitory } \\
\text { effect to } \\
\text { equine } \\
\text { encephalitis }\end{array}$ & $\begin{array}{l}\text { Antibiotic produc- } \\
\text { ed by the strain }\end{array}$ \\
\hline S. griseus & + & - & Grisein-like \\
\hline S. albidoflavus & + & - & Streptothricin A \\
\hline Strain Z-4-1 & + & - & Slightly antibacterial \\
\hline Strain Z-1-4 & + & + & Abikoviromycin \\
\hline Strain Z-5-11 & + & + & Abikoviromycin \\
\hline 10 strains of S. abikoensis & - & + & Abikoviromycin \\
\hline S. rubescens & - & + & Abikoviromycin \\
\hline Other 119 strains (in table 1 ) & - & - & Miscellaneous \\
\hline
\end{tabular}

Comparing the results of Table 1 with those of Table 2, it is found that both experiments gave the same results, except doubtful cases in Table 1.

S. griseus which produced grisein-like antibiotic produced an antiviral substance to Japanese B encephalitis. Further experiment indicated that this antiviral substance was best produced in the medium containing glucose, maltose or dextrin as carbon sources. This substance was not transferred to ethyl acetate at both $\mathrm{pH} 7.0$ and 2.0 in the extraction experiment. $S$. albidofiavus which produced streptothricin A was found to produce an antiviral substance to Japanese B encephalitis. This substance seemed to be different from streptothricin A, because other streptothricin A producing strains did not produce the antiviral substance. The substances effective to western equine encephalitis virus were found to all belong to abikoviromycin by the color test reaction, discovered by Umezawa and others (3). But two abikoviromycin-producing strains were found also to produce the substance effective to Japanese B encephalitis virus. As shown in Table 3, this effective substance was not extracted 
Table 3. Separation of an antiviral substance to Japanese B encephalitis virus of the strain Z-1-4 abikoviromycin

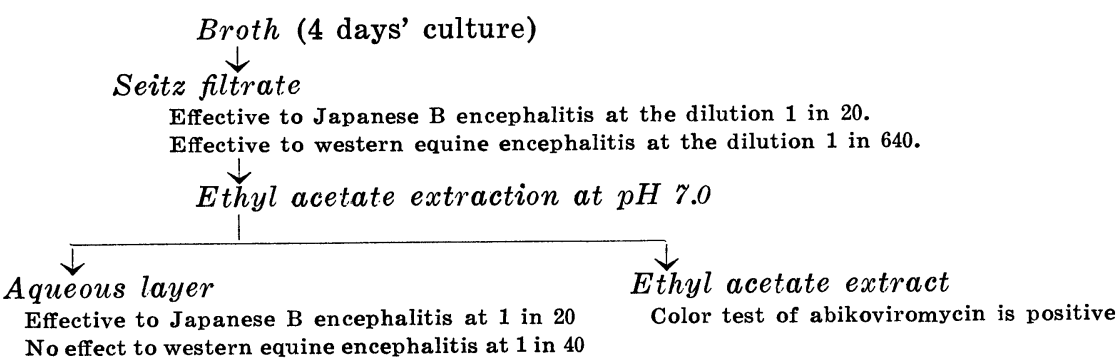

with ethyl acetate and remained in aqueous layer. It was, therefore, concluded to be different from abikoviromycin. The antiviral substance produced by the strain Z-4-1 was further studied in detail and the results are described in the following section. It should be emphasized that all strains gave negative results when the broth filtrate was injected subcutaneously to mice which had been intracerebrally infected with the virus of Japanese $B$ encephalitis or that of equine encephalitis. It means whether the amount $(0.3 \mathrm{ml})$ of the broth filtrate injected was insufficient for the protection, or the broth filtrate contained no antiviral substance effective in the protection test. The results of present experiment seem to indicate the necessity for injecting broth filtrate as much as possible. The injection of $0.5-1.0 \mathrm{ml}$ every day for 3-4 days will make the screening much more sensitive. It is difficult to conclude at present that whether the effective substances screened by injecting the mixture of virus and broth filtrate inactivated the virus before injection or after being injected into animal bodies. In this connection, it is interesting to note that the substance effective to Japanese B encephalitis is not effective to western equine encephalitis and vice versa, suggesting that their effect is not due to their non specific protein denaturating activity. On the other hand, the amount of the filtrate injected into brain was only $0.015 \mathrm{ml}$ and this little amount seems to indicate that the effective substance inactivated the virus before injection. The present results indicate the necessity of screening with both methods, namely, one is the injection of the mixture of virus and broth filtrate and another is the subcutaneous injection of the filtrate or the concentrated filtrate repeated for several times to the infected mice. Moreover, since an antiviral substance is specifically effective against a group of viruses, the broth filtrate should be tested on several kinds of viruses for completeness.

On an antiviral substance, achromoviromycin

The strain Z-4-1, shown in Table 2, was isolated from the garden soil at Suginami-ku, Tokyo, and the study of its characters gave the following results:

Microscopical observations :

Fine branching aerial hyphae beared with cylindrical spores. No spiral. 
Characters on various media:

1) Glycerol Czapek's agar, $27^{\circ} \mathrm{C}$

Colorless to brownish, restricted growth, scant white to dark grayish colored aerial mycelia, brown soluble pigment.

2) Krainsky's glucose asparagine agar, $27^{\circ} \mathrm{C}$

Yellowish brown, restricted poor growth, scant yellowish white aerial mycelia, none or slightly brown soluble pigment (reverse is brown).

3) Nutrient agar, $37^{\circ} \mathrm{C}$

Wrinkled, elevated, colorless to brownish growth, no aerial mycelia, no soluble pigment.

4) Potato plug, $27^{\circ} \mathrm{C}$

Yellowish brown to brownish, fine wrinkled growth, white, powderly aerial mycelia. No soluble pigment at first, later reddish brown.

5) Carrot plug, $27^{\circ} \mathrm{C}$

Brownish, poor growth, no aerial mycelia no soluble pigment.

6) Litmus milk, $37^{\circ} \mathrm{C}$

Poor surface growth, no aerial mycelia, no soluble pigment, coagulation and peptonization very weak.

7) Egg media, $37^{\circ} \mathrm{C}$

Reddish brown, wrinkled growth, no aerial mycelia, no soluble pigment.

8) Loeffler's serum media, $37^{\circ} \mathrm{C}$

Elevated, wrinkled, colorless to brownish growth, no aerial mycelia, no soluble pigment, no liquefaction.

9) Blood agar, $37^{\circ} \mathrm{C}$

Brownish, wrinkled poor growth, no aerial mycelia, no soluble pigment, no hemolysis.

10) Peptone solution added with $\mathrm{NaNO}_{3}, 37^{\circ} \mathrm{C}$

White flaky mass at bottom, no aerial mycelia, no soluble pigment. Nitrite formation positive.

11) Gelatin, $20^{\circ} \mathrm{C}$

Yellowish brown restricted growth, no aerial mycelia, slightly brown soluble pigment, liquefaction very weak.

12) Tyrosinate agar, $27^{\circ} \mathrm{C}$

Yellowish brown, elevated, restricted growth, no aerial mycelia, no soluble pigment, tyrosinase reaction negative.

13) Starch agar plate, $27^{\circ} \mathrm{C}$

Colorless to yellowish growth, scant grayish white aerial mycelia, slightly brownish soluble pigment, enzymatic zone induced by iodine reaction 7-9 $\mathrm{mm}$ in diameter.

Strain Z-4-1 was carefully compared with the descriptions of known species of streptomyces recognized in Bergey's Manual, 6th edition. It resembles Streptomyces diastaticus (Krainsky) Waksman and Henrici, and Streptomyces fimi- 
carius (Duche) Waksman and Henrici according to the key. But it differs from the former in the points of spiral formation, hemolysis, liquefaction of gelatin and proteolytic action of milk, and, it differs from the latter in the points of liquefaction of coagulated serum. Also it differs from any other species. The writers, therefore, concluded that this strain belongs to a new species and proposed to name it as Streptomyces achromogenes OKAMI et Umezawa, because it produces no pigment except on synthetic agar.

Since the species was named Streptomyces achromogenes, its antiviral substance was named achromoviromycin. As shown in Table 4, this substance was

Table 4. Shaking culture of the strain Z-4-1 which produces an antiviral substance to Japanese B encephalitis

\begin{tabular}{|c|c|c|c|c|c|}
\hline \multirow{2}{*}{ Media** } & \multicolumn{5}{|c|}{ Death or survival of mice } \\
\hline & \multicolumn{2}{|c|}{1 in $10^{*}$} & \multicolumn{3}{|c|}{1 in $20^{*}$} \\
\hline Glycerol & $\mathrm{L}_{8} * *$ & $\mathrm{~S}$ & $\mathrm{~L}_{6}$ & $\mathrm{~L}_{7}$ & $\mathrm{~L}_{7}$ \\
\hline Glucose & $\mathrm{L}_{6} \quad \mathrm{I}$ & $\mathbf{S}$ & $\mathrm{L}_{6}$ & $\mathrm{~L}_{7}$ & $\mathrm{~L}_{7}$ \\
\hline Maltose & $\mathrm{L}_{7}$ & $\mathrm{~L}_{8}$ & $\mathrm{~L}_{6}$ & $\mathrm{~L}_{6}$ & $\mathrm{~L}_{6}$ \\
\hline Lactose & $\mathrm{L}_{6}$ & $\mathrm{~L}_{7}$ & $\mathrm{~L}_{7}$ & $\mathrm{~L}_{8}$ & $\mathrm{~L}_{8}$ \\
\hline Dextrin & $\mathrm{S}$ & $\mathbf{S}$ & $\mathrm{L}_{8}$ & $\mathrm{~L}_{9}$ & $\mathbf{S}$ \\
\hline Starch & S & $\mathbf{S}$ & $\mathrm{L}_{6}$ & $\mathrm{~L}_{8}$ & $\mathbf{S}$ \\
\hline Control & & & & & \\
\hline
\end{tabular}

* 1 in 10 indicates the broth filtrate is diluted to 1 in 5 and mixed with the same volume of the virus suspension (10-4 dilution) and injected to mice intracerebrally.

** $\mathrm{L}_{6}$ indicates that the mouse died 6 after days injection. $\mathrm{S}$ indicates that the mouse survived.

** Basal medium contains $0.5 \%$ meat extract, $0.5 \%$ peptone and $0.5 \% \mathrm{NaCl}$. Carbon sources are added at $1.0 \%$.

most well produced in the broth containing dextrin or starch. As organic nitrogen sources, the combination of meat extract and peptone was most suitable (Table 5). The broth was also found to inhibit the growth of Sarcina lutea and this inhibitory effect seemed at first to parallel the antiviral effect to Japanese B encephalitis virus. Moreover, both the antibacterial and antiviral substances were extracted with ethyl acetate at $\mathrm{pH}$ 2.0. But on further examination of the effect of crude extract, this parallelism was not recognized. The antibiotic effective to Sarcina lutea was purified and it was named sarcidin, the description of which is presented in another paper (4). The purified sarcidin inhibited the growth of Sarcina lutea at the dilution of 1 in 640,000 , but it did not show any inhibitory effect to virus at 1 in 200 .

Table 6 summarizes the extraction procedure of the antiviral substance. It is extracted with ethyl acetate at $\mathrm{pH} 2.0$ and concentrated in vacuo at $40^{\circ} \mathrm{C}$. The crude powder was obtained which was effective at the dilution of 1 in 8,000 16,000. Though the powder was highly crude and did not represent the true 
Table 5. The influence of various nitrogen sources on the production of antiviral substance of the strain Z-4-1 effective to Japanese B encephalitis by shaking culture

\begin{tabular}{|c|c|c|c|}
\hline \multirow{2}{*}{ Media* } & \multicolumn{2}{|c|}{ Survival of mice } & \multirow{2}{*}{$\begin{array}{l}\text { Inhibition zone to } \\
\text { S. lutea in mm. }\end{array}$} \\
\hline & $1: 10$ & $1: 20$ & \\
\hline $\begin{array}{l}0.5 \% \text { meat extract } \\
0.5 \% \text { peptone } \\
1.0 \% \text { dextrin }\end{array}$ & $0 / 3$ & $0 / 3$ & 14.5 \\
\hline $\begin{array}{l}0.5 \% \text { meat extract } \\
0.5 \% \text { peptone } \\
2.0 \% \text { dextrin }\end{array}$ & $2 / 3$ & $1 / 3$ & 17.5 \\
\hline $\begin{array}{l}2.0 \% \text { yeast } \\
1.0 \% \text { dextrin }\end{array}$ & $1 / 3$ & $0 / 3$ & 15.5 \\
\hline $\begin{array}{l}1.5 \% \text { soybean meal } \\
1.0 \% \text { dextrin }\end{array}$ & $0 / 3$ & $0 / 3$ & 15.0 \\
\hline $\begin{array}{l}2.0 \% \text { corn steep liquor } \\
1.0 \% \text { dextrin }\end{array}$ & $0 / 3$ & $0 / 3$ & 14.5 \\
\hline $\begin{array}{l}0.5 \% \text { meat extract } \\
0.5 \% \text { peptone } \\
1.0 \% \text { starch }\end{array}$ & $3 / 3$ & $0 / 3$ & 18.5 \\
\hline $\begin{array}{l}0.5 \% \text { meat extract } \\
0.5 \% \text { peptone } \\
2.0 \% \text { starch }\end{array}$ & $3 / 3$ & $1 / 3$ & 21.0 \\
\hline $\begin{array}{l}2.0 \% \text { yeast } \\
1.0 \% \text { starch }\end{array}$ & $0 / 3$ & $0 / 3$ & 13.0 \\
\hline $\begin{array}{l}2.0 \% \text { corn steep liquor } \\
1.0 \% \text { starch }\end{array}$ & $0 / 3$ & $0 / 3$ & 15.0 \\
\hline
\end{tabular}

* Basal medium contained $0.05 \% \mathrm{KCl}, 0.1 \% \mathrm{NaCl}, 0.1 \% \mathrm{~K}_{2} \mathrm{HPO}_{4}$, and $0.05 \%$ $\mathrm{MgSO}_{4} \cdot 7 \mathrm{H}_{2} \mathrm{O}$.

Table 6. Extraction of the antiviral substance, achromoviromycin, produced by the strain $\mathrm{Z}-4-1$

Broth filtrate: $1700 \mathrm{cc}$, antiviral potency $10 \mathrm{u} / \mathrm{cc}$

Ethyl acetate at $\mathrm{pH} 2.0$ : $1175 \mathrm{cc}$

Concentrated in vacuum to $12 \mathrm{cc}$

Added with $2.0 \% \mathrm{NaHCO}_{3}$ to $\mathrm{pH} 7.5$

Volume of the solution: $17 \mathrm{cc}$<smiles>[AlH2]</smiles>

Freez-drying: 480mg, antiviral potency $8-16 \mathrm{u} / \mathrm{mg}$

toxicity of this substance, subcutaneous injection of $20 \mathrm{mg}$ of this substance into mice did not induced any toxic signs. Subcutaneous injection of $10 \mathrm{mg}$ slightly prolonged the survival days of the intracerebrally infected mice. Molisch, Tolens, ninhydrin, Sakaguchi, Millon, Pauli, and ferric chloride tests of the crude powder were all negative.

\section{SUMMARY}

(1) Two methods of screening antiviral substances produced by streptomyces and their results of their actual application were described. 
(2) The broth filtrates of S. griseus which produced grisein or griseinlike substance, S. albidoflavus which produced streptothricin, two strains of S. abokoensis, and the filtrate of a strain Z-4-1 presented an antiviral effect when mixed with Japanese B. encephalitis virus and injected intracerebrally to mice.

(3) The antiviral substance to Japanese B encephalitis produced by S. griseus, and $\mathrm{S}$. abikoensis were not extracted with ethyl acetate both at $\mathrm{pH}$ 2.0 and 7.0 .

(4) A strain Z-4-1 was found to belong to a new species and was named Streptomyces achromogenes Okami et Umezawa. The production of an antiviral substance was observed when shaking cultured in a medium containing meat extract, peptone and dextrin, starch, or glycerol. The antiviral substance was extracted with ethyl acetate at $\mathrm{pH} 2.0$ and named achromoviromycin.

\section{REFERENCES}

(1) Groupé, V., Frankel, J.W., Lechevalier, M.P. and Waksman, S.A.: Antiviral properties of ehrlichin, an antibiotic produced by Streptomyces lavendulae. J. Immunol., 66, 471-482, 1951.

(2) Kochi, M., Weiss, D.W., Pugh, L.H. and Groupé, V.: On viscosin. Bact. Proceedings, p. 29, 1951.

(3) Umezawa, H., Tazaki, T., and Fukuyama, S.: An antiviral substance abikoviromycin, produced by Streptomyces species. Jap. Med. J., 4, 321-246, 1951.

(4) Takeuchi, T., Nitta, K. and Umezawa, H.: On an antibiotic, Sarcidin, produced by S. achromogenes n. sp. J. Antibiot., 6, A, 31-32, 1953. 